\title{
Technological prospecting of the use of vegetables in the development of gluten-free
}

\author{
foods \\ Prospecção tecnológica do uso de vegetais no desenvolvimento de alimentos sem glúten \\ Prospección tecnológica del uso de vegetales en la elaboración de alimentos sin gluten
}

Received: 01/05/2021 | Reviewed: 01/12/2021 | Accept: 01/15/2021 | Published: 01/19/2021

\author{
Luce Alves da Silva \\ ORCID: https://orcid.org/0000-0003-4971-4066 \\ Universidade Estadual do Sudoeste da Bahia, Brazil \\ E-mail: luce_as@hotmail.com \\ Iasnaia Maria de Carvalho Tavares \\ ORCID: https://orcid.org/0000-0002-0478-7977 \\ Universidade Estadual do Sudoeste da Bahia, Brazil \\ E-mail: iasnaiamct@gmail.com \\ Biano Alves de Melo Neto \\ ORCID: https://orcid.org/0000-0001-6490-3274 \\ Instituto Federal de Educação, Ciência e Tecnologia Baiano, Brazil \\ E-mail: biano.neto@ifbaiano.edu.br \\ Cristiane Patrícia de Oliveira \\ ORCID: https://orcid.org/0000-0003-2261-5789 \\ Universidade Estadual do Sudoeste da Bahia, Brazil \\ E-mail: cristianepatricia@uesb.edu.br \\ Marcelo Franco \\ ORCID: https://orcid.org/0000-0002-7827-789X \\ Universidade Estadual de Santa Cruz, Brazil \\ E-mail: marcelofranco@globo.com
}

\begin{abstract}
The growing demand for gluten-free foods, by people seeking more healthiness or who have dietary restrictions, has led to the acquisition of gluten-free foods. However, the development of gluten-free foods is a challenge due to the reduced nutritional value, requiring enrichment from other plant sources. A technological prospection study was carried out on the use of vegetables in the development of gluten-free food products, from October 10 to 18, 2020, by surveying technological information available in national and international patent databases, INPI and ESPACENET, respectively. Search strategies were defined using the association of keywords and international codes relevant to the topic. The results obtained in the international patent base differed by $490 \%$ in the period from 2001 to 2020, when compared with the national database. China stands out as a technology-dominated country, followed by the United States, Canada and Japan. Prospecting based on the number of patent filings revealed a 298\% growth trend for glutenfree products, from 2001 to 2020, according to the international patent base, which emerges as an innovative alternative to meet the trends of the food market for the coming years.
\end{abstract}

Keywords: Patent; Product development; New products; Nutritional value.

\section{Resumo}

A crescente demanda por alimentos sem glúten, por pessoas que procuram alimentos mais saudáveis ou com restrições dietéticas, tem elevado à oferta de novos produtos alimentícios. Entretanto, o desenvolvimento de alimentos sem glúten é um desafio devido ao reduzido valor nutricional, sendo necessário seu enriquecimento a partir de outras fontes vegetais. Realizou-se um estudo de prospecção tecnológica sobre o uso de vegetais no desenvolvimento de produtos alimentícios sem glúten, no período de 10 a 18 de outubro de 2020, mediante o levantamento de informações tecnológicas disponíveis em bases de dados de patentes nacional e internacional, INPI e ESPACENET, respectivamente. Foram definidas as estratégias de busca utilizando associação de palavras-chave e códigos internacionais pertinentes ao tema. Os resultados obtidos na base de patentes internacional divergiram em $490 \%$ no período de 2001 a 2020, quando comparados com a base de dados nacional. A China destaca-se como país com domínio da tecnologia, seguido pelos Estados Unidos, Canadá e Japão. A prospecção com base no número de depósitos de patentes revelou uma tendência de crescimento por produtos sem glúten de $298 \%$, no período de 2001 a 2020, de acordo com a base de patentes internacional, o que desponta como uma alternativa inovadora ao atendimento às tendências do mercado de alimentos para os próximos anos.

Palavras-chave: Patente; Desenvolvimento de produtos; Novos produtos; Valor nutricional. 


\begin{abstract}
Resumen
La creciente demanda de alimentos sin gluten, por parte de personas que buscan alimentos más saludables o con restricciones dietéticas, ha aumentado la oferta de nuevos productos alimenticios. Sin embargo, el desarrollo de alimentos sin gluten es un desafío debido al reducido valor nutricional, que requiere el enriquecimiento de otras fuentes vegetales. Se realizó un estudio de prospección tecnológica sobre el uso de vegetales en la elaboración de productos alimenticios sin gluten, del 10 al 18 de octubre de 2020, mediante el relevamiento de información tecnológica disponible en bases de datos de patentes nacionales e internacionales, INPI y ESPACENET, respectivamente. Las estrategias de búsqueda se definieron mediante la asociación de palabras clave y códigos internacionales relevantes al tema. Los resultados obtenidos en la base de patentes internacional difieren en un $490 \%$ en el período de 2001 a 2020, en comparación con la base de datos nacional. China se destaca como un país dominado por la tecnología, seguido por Estados Unidos, Canadá y Japón. La prospección basada en el número de solicitudes de patente reveló una tendencia de crecimiento del 298\% para los productos sin gluten, de 2001 a 2020, según la base de patentes internacional, que surge como una alternativa innovadora para atender las tendencias del mercado alimentario para los próximos años.
\end{abstract}

Palabras clave: Patente; Desarrollo de produtos; Nuevos produtos; Valor nutricional.

\title{
1. Introduction
}

The food industry has been looking for strategies to meet the demand for healthier foods with greater nutritional value, substituting ingredients in its formulation with others from alternative sources or with restriction of some component (Rodrigues et al., 2020; Taetzsch et al, 2018; Arslain et al, 2021). Among the foods that meet this demand are gluten-free foods (Taetzsch et al, 2018; Arslain et al, 2021). According to market research, people without gluten restrictions buy most glutenfree products, because they believe it is a "healthier" option or because it represents a "very important" attribute when purchasing food (Reilly, 2016).

Gluten-free foods are indicated for individuals with celiac disease, wheat allergy and sensitivity to non-celiac gluten, medical conditions that require a gluten-free diet, since no other therapy is currently available (Reilly, 2016; Melini \& Melini, 2019).

The development of gluten-free products is a challenge because they have reduced nutritional value, in addition to having a lower taste and taste, when compared to conventional products with gluten (Arslan et al, 2019; Babio et al, 2020). Compared to conventional products, gluten-free products usually have a higher amount of calories, fat and sodium, and reduced content of vitamin B12, folate, niacin, vitamin D, iron, zinc, magnesium, calcium, dietary fiber and protein (Taetzsch et al, 2018; Melini \& Melini, 2019; Arslain et al, 2021).

To add nutritional and functional value to gluten-free products, ingredients are added that confer nutritional and sensory quality attributes, promoting product differentiation and diversifying the market, with a reflection on the price of products (Gorgitano \& Sordano, 2019).

Several studies have been published, related to the incorporation of ingredients of plant origin, especially cereals and legumes, as a strategy for the development of gluten-free products, with better rheological and texture characteristics, greater nutritional value and sensory quality ( $\mathrm{Li}$ et al, 2020; Bassinello et al, 2020; Diniz et al, 2020; Chis et al, 2020; Raymundo, Torres \& Sousa, 2020).

That said, it is intended to carry out a technological prospection study based on patent documents and scientific articles, on the use of vegetables in the development of gluten-free food products.

\section{Methodology}

In order to carry out scientific research, a qualitative and quantitative study, as defined by Pereira et al., (2018), was carried out based on the search for patent documents and scientific articles, in the period from 10 to 18 October 2020. 
The technological prospecting was carried out in a national and international patent database, INPI and ESPACENET, respectively, according to the adapted methodology proposed by Pereira Filho et al., (2020). To conduct searches in technological prospecting, the codes A21D were initially used, which refers to the treatment, for example, preservation of flour or dough, for example, by adding materials; to bake; bakery products; preserving them; and A23L, which refers to food, food products or non-alcoholic drinks, not covered by subclasses A23B - A23J; preparation or treatment. Refining the search, in order to achieve the objective of verifying the use of vegetables in the composition of gluten-free food products, in addition to the previous codes, the following keywords were used: food, gluten-free and vegetables, which resulted in 373 patents. The Boolean operator used was "and", to limit searches to terms used together. For searches in the national database, the term "gluten-free" was used as a keyword.

In order to compare the number of patents and scientific production, a scientific survey was carried out with the search for articles related to the topic in the Science Direct database, from 2000 to 2020, to evaluate research trends in the world. of food technology involving gluten-free foods. For that, the keywords were used: food, gluten free and vegetables.

The prospecting was developed only in Microsoft Excel, manually, not using, therefore, technological prospecting software.

\section{Results and Discussion}

According to the predefined search criteria, the search in the international patent base, ESPACENET, has identified the registration of 373 patents. From the results obtained, it can be seen in Figure 1 that most of the patents registered on the international basis are distributed among 8 countries.

Figure 1. Patent deposit by country.

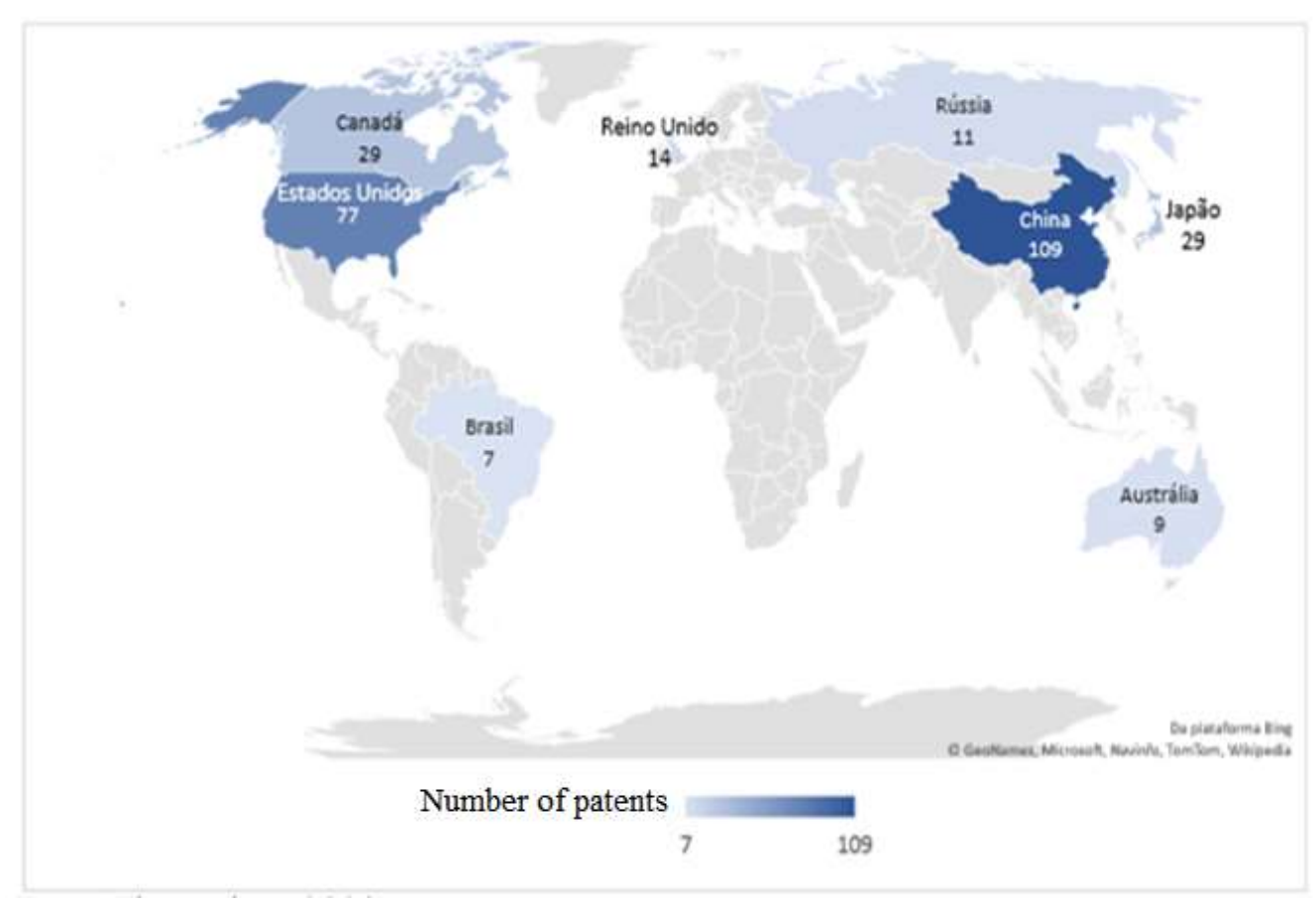

Source: Authors (2020). 
Based on the results obtained on the basis of ESPACENET, Figure 1 presents the relevance of China, as a country with a domain of technology, with 109 patents, followed by the United States (77 patents), Canada (29 patents) and Japan (29 patents).

According to Figure 2, it is observed that most of the depositors of the two bases considered are companies, followed by individuals and universities.

Figura 2. Main depositors of the international and national base.

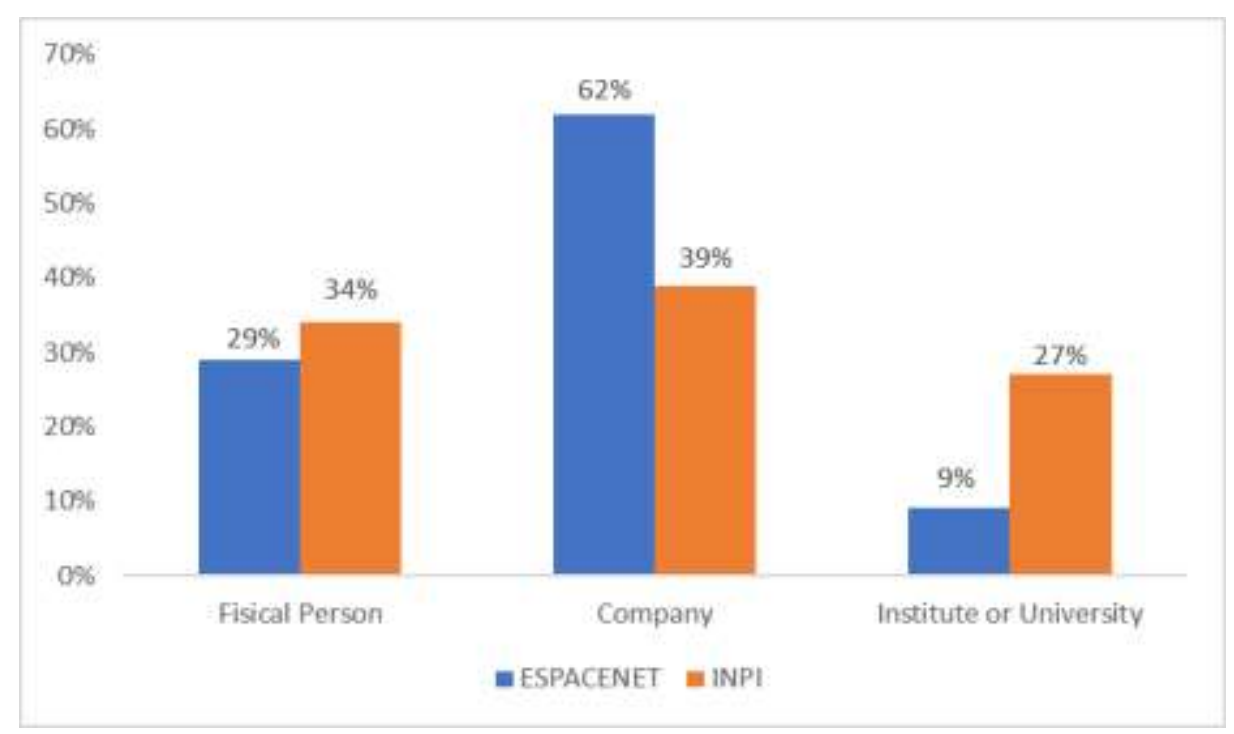

Source: Authors (2020)

According to Figure 2, which presents the main depositors of the international and national base, it is observed that in the international patent base, there is a more expressive difference between the depositors, with $62 \%$ referring to companies, $29 \%$ to individuals and only $9 \%$ refer to institutes or universities. In the national patent base, this difference is more discreet, with $39 \%$ of the patent registration originating from companies, $34 \%$ from individuals and $27 \%$ from institutes or universities.

The results of the search for patents in the international database showed that there was no registration of companies in the base searched and that, of the 7 registrations originating in Brazil, only 1 was related to an educational institution. The Federal University of Brasilia (UNB) is the only Brazilian educational institution that holds a patent (BRPI0903673A2), whose title is: "Pasta made from gluten-free green banana flour, obtaining process and its application".

These findings are in contrast to that described by Barros, Anjos e Barros (2020), who claim that the largest investments come from the government, through universities. Although the leadership of the patent registration is of companies, this participation is still discreet, which, according to the same author, is due to the lack of investment in Research and Development.

According to Table 1, it is observed that 3 companies are responsible for more than 10 patents surveyed, most of them originating in the United States. 
Table 1. Main filing companies, country of origin and number of patents.

\begin{tabular}{lll}
\hline Company & Country of Origin & Deposit Number \\
\hline NESTLÉ COMPANY & China & 4 \\
KRAFT FOODS HOLDINGS INC & USA & 4 \\
CARGILL INC & USA & 3 \\
TASTEMAKER & USA & 2 \\
BUNGE OILS INC & USA & 1 \\
\hline
\end{tabular}

Source: Authors (2020).

Based on Table 1, it can be seen that the 3 companies that hold the largest number of patent filings on the international basis are Nestlé S.A., Kraft Foods Holding Inc. and Cargill Inc., with 4, 4 and 3 patents, respectively.

When comparing the international patent base with the national patent base, it is observed that both have a tendency for the growth of gluten-free products, and the national base shows a later and discreet evolution, as can be seen in Figure 3 .

Figure 3. Distribution of patent deposits on the ESPACENET and INPI bases, from 1938 to 2020.

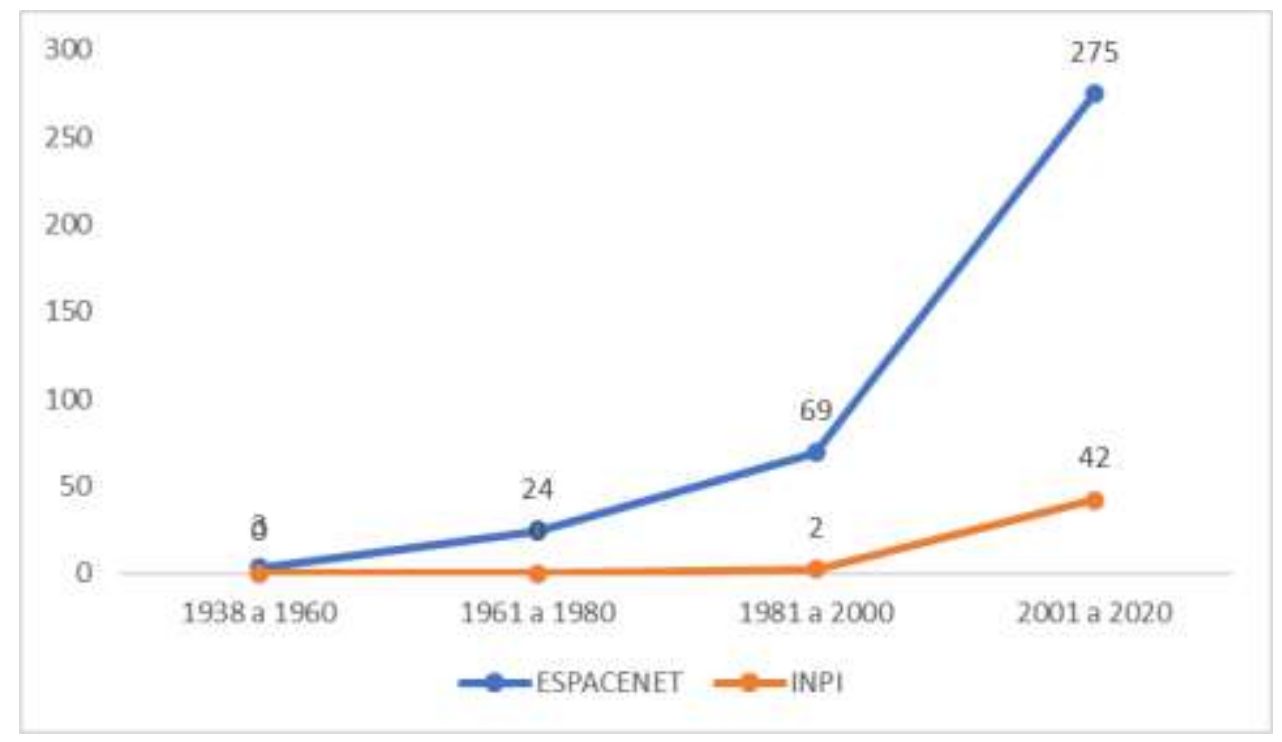

Source: Authors (2020)

In Figure 3, which addresses the distribution of patent deposits on the ESPACENET and INPI bases between the years 1938 and 2020, it is observed that the international base revealed a growth trend for gluten-free products, with the registration of 206 patents, in the 2001 to 2020, which corresponds to a $298 \%$ increase in the analyzed patent base. When comparing the international and national patent base, there is a difference of 233 patents, in the same period, which corresponds to a difference of $490 \%$, between the two bases analyzed.

The 44 patents nationally registered, 12 are related to the development of gluten-free bakery products.

Like scientific prospecting, the proposed articles were published between 2000 and 2020 . When analyzing the Figure 4 , can see that the number of published articles related to gluten-free foods, it can be seen that the distribution reveals a growth in the interest of studies, since 2000. 
Figure 4. Result of scientific research on gluten-free foods, from 1938 to 2020.

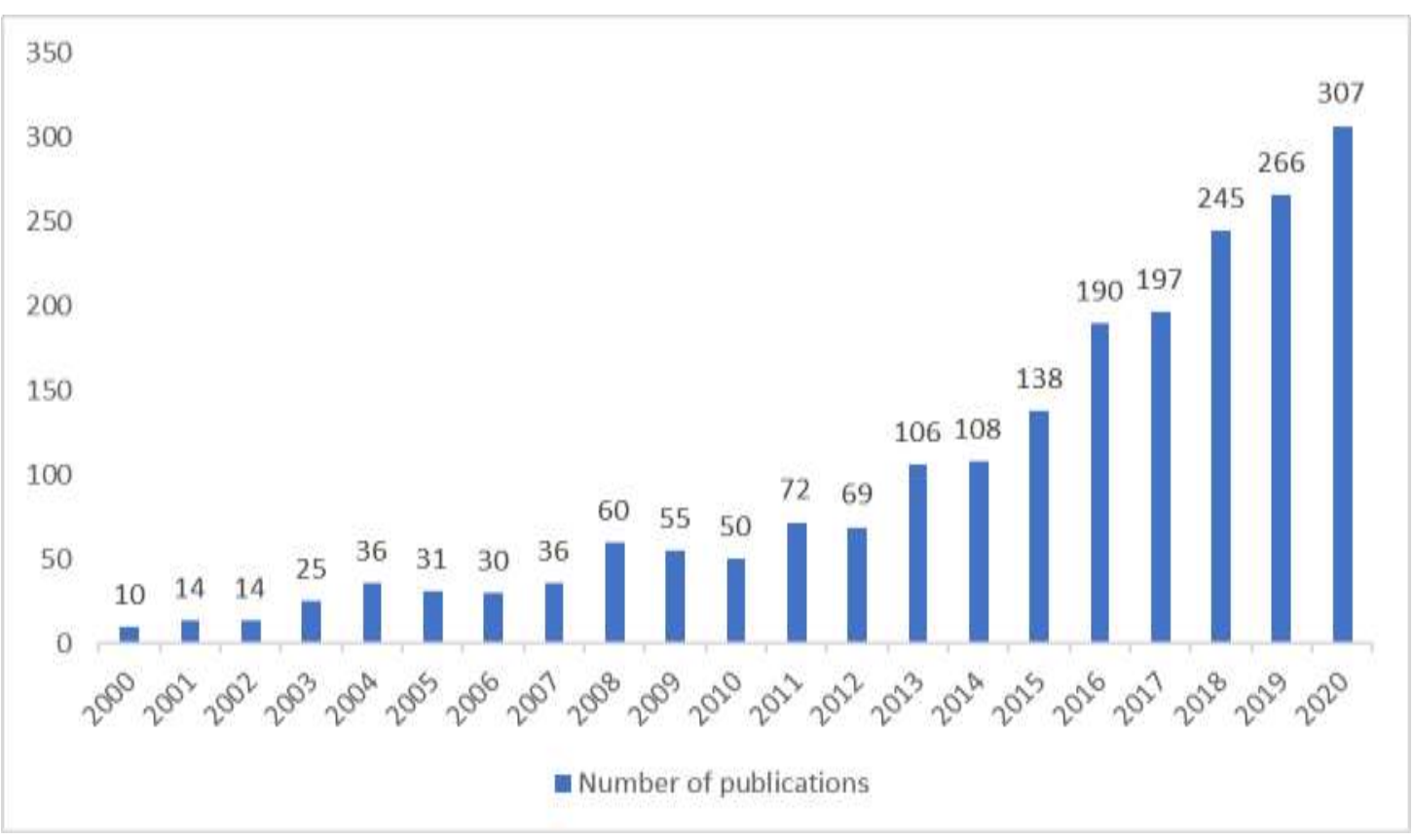

Source: Authors (2020).

According to Figure 4, which shows the results of scientific research in the period from 2000 to 2020, it is observed that, in the year 2000, only 10 articles were published on the topic of gluten-free foods. In 2020, 307 articles related to the same theme were published, which shows a relevant increase during the analyzed period.

Although there was no selection and disposal of articles unrelated to the topic, a large number of documents were identified involving the effects of gluten-free eating in people with celiac disease. This reveals that research for the development of gluten-free foods are scarce, which is a promising topic for investments in research, development and appropriation of technology.

\section{Conclusion}

The results of the prospecting study indicate that Brazil, in comparison to the other countries, has a low participation in this technology, although it presents a growth trend. The search for scientific content revealed an evolution regarding the use of vegetables in the development of gluten-free products, being favorable to the development of new research.

Gluten-free food products present themselves as an innovative alternative in the development of new products capable of meeting the trends of the food market for the coming years. Thus, it is necessary to develop studies in the area, aimed at the development of new products that meet the dietary restrictions of the consumer market, aiming to provide greater variety and add nutritional quality.

\section{Acknowledgements}

The authors would like to thank the Coordination for the Improvement of Higher Education Personnel (CAPES, Brazil), the National Council for Scientific and Technological Development (Productivity in Research Grants 302259 / 2018-0, CNPq, Brazil), and the Research Support Foundation of the State of Bahia (FAPESB, Brazil) and the State University of Southwest Bahia (UESB) for their financial assistance, the State University of Santa Cruz (UESC) 


\section{References}

Arslain, K., Gustafson, C. R., Baishya, P., \& Rose, D. J. (2021). Determinants of gluten-free diet adoption among individuals without celiac disease or nonceliac gluten sensitivity. Appetite, 156, 1049582021. https://doi.org/10.1016/j.appet.2020.104958

Arslan, M., Rakha, A., Xiaobo, Z., \& Mahmood, M. A. (2019). Complimenting Gluten Free Bakery Products with Dietary Fiber: Opportunities and Constraints. Trends in Food Science \& Technology, 83, 194-202. https://doi.org/10.1016/j.tifs.2018.11.011

Babio, N., Bellette, N. L., Besora-Moreno, M., Castillejo, G., Guillén, N.; Martínez-Cerezo, F., Vilchez, E., Roger, E., Hernández-Alonso, P., \& SalasSalvadó, J. (2020). A comparison of the nutritional profile and price of gluten-free products and their gluten-containing counterparts available in the Spanish Market. Nutrición Hospitalaria, 37(4), 814-822. http://dx.doi.org/10.20960/nh.03016

Barros, G. M. de., Anjos, M. S. dos, \& Barros, G. M. (2020). Prospecção Tecnológica de Pequizeiro (Caryocar brasiliense Camb.). Research, Society and Development, 9(9), e754997957. https://doi.org/10.33448/rsd-v9i9.7957

Bassinello, P. Z., Bento, J. A. C., Gomes, L. O. F., Caliari, M., \& Oomah, B. D. (2020). Nutritional value of gluten-free rice and bean based cake mix. Ciência Rural, 50(6), e20190653. https://doi.org/10.1590/0103-8478cr20190653

Chis, M. S., Paucean, A., Man, S. M. Muresan, V., Socaci, S. A., Pop, A., Stan, L., Rusu, B., \& Muste, S. (2020). Textural and Sensory Features Changes of Gluten Free Muffins Based on Rice Sourdough Fermented with Lactobacillus spicheri DSM 15429. Foods, 9(363), 1-17. https://doi.org/10.3390/foods 9030363

Diez Garcia, R. W. (2003). Reflexos da globalização na cultura alimentar: considerações sobre as mudanças na alimentação urbana. Revista de Nutrição, 16(4), 483-492. https://doi.org/10.1590/S1415-52732003000400011

Diniz, R. C., Coura, F. M., \& Rodrigues, J. F. (2020). Effect of different gluten-free flours on the sensory characteristics of a vegan alfajor: Vegan gluten-free Alfajor development. Food Science Technology International.1-6. https://doi.org/10.1177/1082013220939792

Gorgitano, M. T., \& Sodano, V. (2019). Gluten-Free Products: From Dietary Necessity to Premium Price Extraction Tool. Nutrients, 11(9), 1997. http://dx.doi.org/10.3390/nu11091997

Li, M., Sun, H-N., Mu, T-H., Tian, S-L., Ji, L-L., Zhang, D-Q., Li, S-Q., Ge, X., Cheng, J-X., \& Tian, J-C. (2020). Preparation and quality characteristics of gluten-free potato cake. Food Processing and Preservation, 44(11), e14828. https://doi.org/10.1111/jfpp.14828

Melini, V., \& Melini, F. (2019). Gluten-Free Diet: Gaps and Needs for a Healthier Diet. Nutrients, 11(1), 170. http://dx.doi.org/10.3390/nu11010170

Pereira, A. S., Shitsuka, D. M., Parreira, F. J., \& Shitsuka, R. (2018). Metodologia da pesquisa científica. UAB/NTE/UFSM.

Pereira Filho, J. L., Gerônimo Neto, P. da. S., Monteiro, P. de. M., Ferreira, J. M. S., Pinheiro, A. de. A., Rodrigues, C. D. P., \& Vilanova, C. M. (2020). Prospecção tecnológica dos efeitos biológicos de plantas do gênero Jatropha. Research. Society and Development, 9(9), e04996630. http://dx.doi.org/10.33448/rsd-v9i9.6630

Raymundo, A., Torres, M. D., \& Sousa, I. (2020). Special Issue: Rheology and Quality Research of Cereal-Based Food. Foods, 9(11), 1517. https://doi.org/10.3390/foods9111517

Reilly, N. R. (2016). The Gluten-Free Diet: Recognizing Fact, Fiction, and Fad. The jornal of pediatrics, 175, 206-210. https://doi.org/10.1016/j.jpeds.2016.04.014

Rodrigues, L. M. A., Bispo, J. L. P., Silva, A. G. da, Gualberto, S. A., Silva, L. F. N., Tavares, I. M. de. C., \& Oliveira, C. P. de. (2020). Chemical prospection and biological potential of tropical fruit waste extracts. Research, Society and Development, 9(8), e833986476. https://doi.org/10.33448/rsd-v9i8.6476

Taetzsch, A., Das, S. K., Brown, C., Krauss, A., Silver, R. E., \& Roberts, S. B. (2018). Are Gluten-Free Diets More Nutritious? An Evaluation of Self-Selected and Recommended Gluten-Free and Gluten-Containing Dietary Patterns, Nutrients, 10(12), 1881. https://doi.org/10.3390/nu10121881 